\title{
Structure and development of pitch canker infected Monterey pine stands at Año Nuevo, California
}

\author{
Douglas D. Piirto ${ }^{\mathrm{a}}$, Sauli Valkonen ${ }^{\mathrm{b}, *}$ \\ ${ }^{a}$ Natural Resources Management Department, California Polytechnic State University, San Luis Obispo, CA 93407, USA \\ ${ }^{\mathrm{b}}$ Finnish Forest Research Institute (Metla), Vantaa Research Center, P.O. Box 18, FIN-01301 Vantaa, Finland
}

\begin{abstract}
The sustainability of indigenous Monterey pine (Pinus radiata D. Don) at Año Nuevo stands in the central coast of California was examined. The foremost management objective in these stands is to establish and maintain stand structures that ensure a sustainable presence of the species in terms of uneven-aged management. The major threats are the proliferation of shadetolerant tree species and the pitch canker (Fusarium circinatum) disease. The study was based on data from 17 systematically placed sample plots, measured once, in one stand with a very high degree of variation in stand structure and species composition. The results indicated that the sustainability of Monterey pine is not assured by existing stand structures. Monterey pine regeneration is almost completely lacking. Intensive shading and competition from high stand densities of shade-tolerant broadleaf trees are inhibiting regeneration, and growth of seedlings and saplings. Pitch canker is affecting growth, vigor, and competitive status of Monterey pine, but its progress and long-term impact remain unknown. Single tree or group selection cuttings, combined with treatments that enhance regeneration, are urgently required for the promotion of Monterey pine.
\end{abstract}

Keywords: Growth; Modeling; Pinus radiata; Selection management; Silviculture; Stand structure; Stand dynamics

\section{Introduction}

The indigenous Monterey pine (Pinus radiata $\mathrm{D}$. Don) forest occurred as a part of a continuous forest of closed-cone pine species on the coast of California and adjacent Pacific islands as recently as the late Pleistocene Epoch some 12000-14500 years ago
(Jones and Stokes Associates, 1994). This continuous forest became fragmented as climates became hotter and drier, resulting in repeated local extinctions and colonizations (Burdon et al., 1992; Rogers, 2002), so that only five isolated indigenous populations of Monterey pine exist today. Three occur on the California mainland: Año Nuevo, Monterey, and Cambria, and two on the Pacific Guadalupe Cedros Islands. Various estimates ranging between 50008000 ha have been made as to their present extent (McDonald and Laacke, 1990; Hakkila, 1994; Huffman 
and Associates Inc., 1994; Jones and Stokes Associates, 1994). Between and within populations, significant variation occurs in stand composition from relatively pure stands to mixed stands to isolated occurrences of Monterey pine.

Monterey pine is one of the most widely planted tree species in the world. Monterey pine plantations were reported in 1990 to occupy some 3.5 million hectares worldwide (Lavery, 1990; Hakkila, 1994). The five indigenous Monterey pine populations constitute a critical source of genetic material for the species, upon which the long-term success of the commercial and ornamental plantations may ultimately depend. Considerable areas have been lost to development, and the natural forest ecosystems have become increasingly fragmented (Rogers, 2002).

The forest practice rules for Santa Cruz and Monterey counties (California Forest Practice Rules, 2003) preclude the application of even-aged management systems and implicitly impose uneven-aged management on Monterey pine stands. Gap regeneration and group selection are permitted in addition to single tree selection.

The natural stand dynamics and the ecology of Monterey pine do not seem to offer particularly good opportunities for the application of selection management. It is classed as intermediate in shade-tolerance, i.e. as tolerant as any other pine in Western North America (McDonald and Laacke, 1990). The closedcone species depends on hot fires for a dense seed rain and bare seedbed. However, some cones open in ambient air temperatures giving a sparse seed rain in most years, and some seedlings are usually present in the native stands. Consequently, all-aged stands of natural Monterey pine occur but the size class distribution is usually markedly skewed to the trees that originated after the last hot fire (White, 1999).

The most serious threats to the native Monterey pine forest are the proliferation of shade-tolerant tree species and the pitch canker disease. Few studies have been conducted on the sustainability of existing stand structures of indigenous Monterey pine in the pitch canker context. White (1999) concluded that existing Monterey pine stands with increasing levels of pitch canker mortality and lack of prescribed fire would become dominated by shade-tolerant oaks. As such, the purpose of ongoing research is to determine if uneven-aged management systems can promote regeneration, survival and growth of Monterey pine, as well as help reduce the impacts of pitch canker (Storer et al., 2001).

The Año Nuevo forests were often burned in the first half of the 1900s. Three mixed severity fires occurred from the late 1800s-2001 (1936, 1948, and 1957), favoring Monterey pine regeneration. Low severity fires were common until the 1960s, partly due to prescribed burning on the adjacent rangelands (Stephens et al., 2004). Since then, in the absence of major fires, Douglas-fir and Coast redwood have tended to outcompete Monterey pine except on poor soils and possibly on coastally exposed slopes (Jones and Stokes Associates, 1994). The absence of fire is a major factor for the high level of presence and even dominance of oaks in the pine stands, because the bark of oaks is a relatively poor insulator (White, 1999). Coast live oak/Shreve oak is the principal colonizing shade tolerant oak species in Scotts Creek. The structure, dynamics, and history of the Scotts Creek stand are representative of those in the Año Nuevo stands in general (Walter R. Mark, Cal Poly, personal communication, December 2003).

Since the late 1980s, Pitch canker (Fusarium circinatum Nirenberg and O'Donnell $[=F$. subglutinans (Wollenw \& Reinking) Nelson et al. f. sp. pini]) has become a major cause of growth loss, mortality, and associated economic impacts in California Monterey pine trees and forests (Matthews and Nedeff, 1995; Adams, 1997; Gordon et al., 1997; Owens, 1997; Templeton et al., 1997). The fungus causes girdling lesions on branches, roots, and main stems of trees. They can cause extensive die-back in the crown and may lead to death of the tree, directly or by predisposing trees to infestations by bark beetles (Wikler et al., 2003). There are no studies that have fully evaluated the implementation of even- or uneven-aged forest management strategies in Monterey pine stands in California. Only in recent years have interim strategies for slowing the spread of pine pitch canker and conserving Monterey pine been developed (Huffman and Associates Inc., 1994; California Forest Pest Council-Pine Pitch Canker Task Force, 1995; Matthews and Nedeff, 1995; Cylinder, 1997; Gordon et al., 1997; Owens, 1997; Storer et al., 2001). These interim strategies, however, require further validation through scientific study. 
There remains a strong need for science-based forest management guidelines for the Monterey pine forests in California given the high public interest and concern over the spread of pitch canker and the decline of the Monterey pine forest. The objective of the study is to provide answers to the following management questions:

- What kind of stand structures do the Año Nuevo Monterey pine stands currently display?

- How are trees of different species and sizes growing in diameter, subject to stand density and the competition between individuals?

- What is the influence of the pitch canker infestation on the growth and survival of Monterey pines, not only directly but as one of the factors that control the dynamics of a whole stand?

- How much regeneration of Monterey pine and conifers in general is present?

- Do the current stand structure and dynamics facilitate the development towards sustainable uneven-aged stands with increasing proportion of Monterey pine in the near future?

- What kind of management activities would promote sustainability of Monterey pine?

\section{Material and methods}

\subsection{Study stand}

The study was conducted at the Scotts Creek stand on the Cal Poly University School Forest at Swanton Pacific Ranch on the central coast of California, just north of Santa Cruz. The habitat is strongly influenced by its proximity to the Pacific Ocean, resulting in a mild climate with high humidity, low temperatures, and summer fogs. The stand constitutes a compact management unit of about 106 hectares of forest land. Monterey pine is concentrated on the western part of the stand on gentler slopes and partly level ground, with a complex borderline between the forest and rangeland. Pure groups and stands of Monterey pine occur on the western border. Everywhere else Monterey pine grows in admixture with Douglas-fir (Pseudotsuga menziesii var. menziesii (Mirbel) Franco), coast redwood (Sequoia sempervirens (D. Don) Endlicher), California nutmeg (Torreya californica Torrey), and variable proportions of broadleaved species A variety of broadleaf species have been found in the Scotts Creek stand. The most dominant group is coast live oak (Quercus agrifolia Nee) and Shreve oak (Quercus parvula var. shrevei (C. H. Muller)), which hybridize and are hard to separate in the field (Hickman, 1993). Shreve oak seems to be more abundant than coast live oak in Scotts Creek (Walter R. Mark, Cal Poly, personal communication, December 2003) The other major broadleaf species are California buckeye (Aesculus californica (Spach) Nutt.), California bay (Umbellularia californica (Hook. \& Arn.) Nutt.), Tan oak (Lithocarpus densiflora (Hook. \& Arn.) Rehd.), Pacific madrone (Arbutus menziesii Pursh.), bigleaf maple (Acer macrophyllum Pursh.), red alder (Alnus rubra Bong.), boxelder (Acer negundo L.), and arroyo willow (Salix lasiolepis Benth.) (Auten, 2000). The broadleaved species and California nutmeg are generally shorter trees than the conifers and generally occur as lower canopy layers with very high density and crown coverage in places. Towards the east and down the steeper slopes towards Scotts Creek the proportion of Monterey pine decreases and is rapidly canceled out almost completely. Pitch canker was first confirmed in 1992 at Año Nuevo (Storer et al., 1995, 1997) and in 1997 in Swanton Pacific, and it spread throughout the Scotts Creek stand very rapidly. In 1999, the Continuous Forest Inventory sample indicated a 90\% infection rate for the Monterey pines (Auten, 2000).

\subsection{Sampling and measurements}

A continuous forest inventory (CFI) was conducted in the Scotts Creek stand in 1999 (Auten, 1999, 2000). A total of 46 sample plot midpoints were placed on a $152.5 \mathrm{~m} \times 152.5 \mathrm{~m}$ grid over the forested area. A circular plot of 0.081 ha was measured on each midpoint. All trees with a breast height diameter (d) $>2.54 \mathrm{~cm}$ were measured for diameter at breast height $(d)$, species, bearing (dir) and distance $(s)$ from plot midpoint. Conifers were additionally measured for height $(h)$, crown class (dominant, co-dominant, intermediate, or suppressed), and height to crown base. The presence of damage and disease was assessed. The severity of the pitch canker infection (PC) was assessed (Table 1). The presence of other 
Table 1

Classes and resulting distribution for the presence and severity of pitch canker infection in Monterey pine trees $(d>2.54 \mathrm{~cm})$ in the Scotts Creek stand in 1999 (Auten, 2000)

\begin{tabular}{lll}
\hline Code & Explanation & $\begin{array}{l}\text { Proportion of } \\
\text { trees }(\%)\end{array}$ \\
\hline PC D & Pitch canker, dead & 10 \\
PC 1 & Pitch canker, bole cankers & 14 \\
PC 2 & Pitch canker, top dead & 16 \\
PC 3 & $\begin{array}{l}\text { Pitch canker, most }(\geq 50 \%) \\
\text { branches infected }\end{array}$ & 24 \\
& PC 4 4 & 15 \\
& branches infected & \\
PC 5 & Pitch canker, few $(\leq 9 \%)$ & 20 \\
& branches infected & \\
NPC & No pitch canker & 10 \\
\hline
\end{tabular}

diseases and damages independent of PC infection were also assessed. One randomly selected dominant or co-dominant conifer tree was cored for age at breast height $\left(t_{1.3}\right)$ on each plot. Conifer regeneration (trees with $d \leq 2.54 \mathrm{~cm}$ ) was assessed on a 0.04 ha circular sub-plot, and the crown coverage percentage of small broadleaves and understory vegetation was assessed.

In terms of the CFI, the stand was divided into two aggregations (Auten, 2000). The plots (17) with at least one Monterey pine tree of $d>2.54 \mathrm{~cm}$ were assigned to the Monterey pine aggregation (MPA). The rest of the timbered area (29 plots) was assigned to the redwood and Douglas-fir aggregation (RDA). Data from the plots assigned to the Monterey pine aggregation were used in this study, constituting a wide range of variation in stand density and species composition (Table 2).

In summer 2000 and 2001, increment samples were taken of Monterey Pine, Douglas-fir, and coast live oak/ Shreve oak trees within $12.20 \mathrm{~m}$ from the plot center. The goal of the structured sampling framework was to get a balanced sample of trees by species and diameters. An increment borer sample was taken at breast height,

Table 2

Basic data of the sample plots within the Monterey pine aggregation

\begin{tabular}{|c|c|c|c|c|}
\hline Variable & Average & S.D. & Minimum & Maximum \\
\hline Basal area $\left(\mathrm{m}^{2} \mathrm{ha}^{-1}\right)$ & 44.0 & 21.1 & 0.3 & 84.0 \\
\hline \multicolumn{5}{|c|}{ Proportion of species of basal area (\%) } \\
\hline Monterey pine & 32.6 & 32.3 & 0.0 & 100.0 \\
\hline Douglas fir & 17.7 & 23.8 & 0.0 & 72.0 \\
\hline Maximum tree diameter $(\mathrm{cm})$ & 91.1 & 34.1 & 37 & 154 \\
\hline
\end{tabular}

and the cores were measured for annual radial increments. In all, 77 pine and 40 Douglas-fir increment samples with at least four annual radial increment observations were obtained. No increment data were obtained for coast live oak and Shreve oak, because these species do not form distinguishable annual rings. Consequently, nine plots $(1,5,11,20,29,36,37,38,45)$ dominated by the conifers ( $>50 \%$ of basal area) were used for the analyses, including modeling. In order to minimize influence from neighboring trees, all trees with $d>25.4 \mathrm{~cm}$ were measured outside the original CFI plot up to $22.88 \mathrm{~m}$ distance.

\subsection{Analyses and modeling}

Stand structure (diameter distribution, species composition, spatial structure) was subjectively assessed through tabulation and plotting of the data, and visual interpretation of three-dimensional reproductions constructed from the measured data with the Stand Visualization System (McGaughey, 2001).

Tree growth and the development of indigenous Monterey pine stands has not been modeled before. The extensive plantation forests in Australia, New Zealand, and elsewhere have been intensively modeled. An attempt to apply those models was not considered worthwhile, because tree forms, stand structures, species composition, and management are totally dissimilar. Individual tree models were developed to describe tree basal area increment $\left(i_{\mathrm{g}}\right)$ subject to tree size, pitch canker infection, stand density, site, and tree interaction (competition index). Mixed linear models were fit into the data of repeated measurements and hierarchical sampling structure.

The pitch canker rating was used as an independent variable in the Monterey pine growth models. All the branch infection classes were combined to variable PCBRANCH, and the bole and top classes to PCBOLE. The PC free observations (No PC) constituted the reference level.

A distance dependent competition index was applied to describe tree interaction in the models. The index of Hegyi (1974) performed best, and its formulation in (Biging and Dobbertin, 1992) was used with slight modifications:

$$
\mathrm{CIH}_{j m}=\sum_{j \neq m} d_{m} / d_{j}\left(s_{j m}+1\right)
$$


where $\mathrm{CIH}_{j m}$ is the competition index for subject tree $j$, including competitors $m ; d_{j}$ is the diameter of subject tree $j,(\mathrm{~cm}) ; d_{m}$ is the diameter of competitor tree $m$, (cm); $s_{j m}$ is the distance from tree $j$ to tree $m,(\mathrm{~m})$.

Stand basal area was additionally used to account for the influence of stand density as a whole (Weiner and Thomas, 1986; Hara, 1988; Weiner, 1990). There was neither a site index system for Monterey pine nor a site classification system available for description of site productivity. A plot level soil moisture class variable (mesic/xeric) had a strong correlation with tree increment for Douglas-fir and it was applied in the growth model.

The constructed models were used to analyze tree growth, tree interaction and stand dynamics. Tree and stand development in three treatment alternatives were examined using a simulation system based on the growth models ( 3 and 4 ). The purpose was to describe what would happen to the trees and the stand structures on each of the nine conifer dominated plots during 20 years following group or single tree selection, or no treatment.

The purpose of a group selection treatment would be to promote regeneration and growth of small conifer trees. Since Monterey pine is an intolerant species, the maximum circular gap size ( 0.045 ha) that could be fitted on a CFI plot was selected. All trees except small conifers $(d \leq 25 \mathrm{~cm})$ were assured to be removed. Gaps were placed at $40.56 \mathrm{~m} \times 40.56 \mathrm{~m}$ intervals, and the rest of the stand would be left untreated. The values of the object variables for the treatment were thus calculated as weighted averages within the gap (weight $=0.4925$ ) and in the no treatment $(0.5075)$ alternative.

The purpose of single tree selection would be to promote development of the conifers, and launch a development towards a selection structure with increasing proportion of Monterey pine. The same basal area was retained as in the group treatment (weighted value). First 1-4 large conifers were removed from the largest diameter classes $(d>60$ $100 \mathrm{~cm}$ ). The removal probability of each candidate was weighted with its competition pressure on smaller Monterey pines. Next, a proportion (20-85\%) of the larger broadleaf trees $(d>25 \mathrm{~cm})$ was selected with the same kind of procedure. Finally, the plot-specific basal area limits were achieved through the random selection of smaller broadleaf trees. The no treatment alternative aimed at suggesting what would happen if the current trends continued without major disturbance, and served as a basis for comparison to the other two.

There were no data, models nor external information available for the prediction of mortality, whether due to disease and damage including pitch canker, competition and stand density, or other random factors. However, a maximum stand basal area limit (maximum in the data, $68 \mathrm{~m}^{2} \mathrm{ha}^{-1}$ ) was defined to prevent unfounded extrapolation in the predictions. If the basal area exceeded that value, trees were randomly removed until the basal area was below the limit. Trees with a severe pitch canker infection were (bole canker, top dead, or $>50 \%$ branches infected) were assigned a $20 \%$ higher mortality rate. There was no way to predict regeneration, ingrowth, and the delay in thinning response. The simulation results were described comparing development in each treatment in terms of the proportion of Monterey pine of basal area, and diameter growth of small Monterey pine trees $(d \leq 25 \mathrm{~cm})$.

\section{Results}

\subsection{Pitch canker infection}

Only $10 \%$ of the Monterey pine trees with $d>2.54 \mathrm{~cm}$ in the Scotts Creek stand had no signs of pitch canker (PC) infection (Table 1). Most pines $(59 \%)$ had a various degree of branches infested, but $30 \%$ had symptoms on their boles or their top was dead. They could also have various amounts of infested branches. Some trees (1\%) had apparently died because of PC. Saplings $(d<2.54 \mathrm{~cm})$ were less often infected than small trees $(d \geq 2.54 \mathrm{~cm}): 54 \%$ of them were free of PC symptoms, whereas $32 \%$ were dead, probably at least partly due to PC. The rest (14\%) had PC on their bole or branches. Trees without PC infection were smaller (average diameter $15.0 \mathrm{~cm}$ ) than those that had PC $(42.5 \mathrm{~cm})$ and generally belonged to the lower canopy layers There was no correlation between PC infection and stand density. The results in Fig. 1 show, albeit in not a very consistent pattern, that the trees infected in 1999 had already grown slightly slower from 1995 to 1997 , but the difference to healthy trees became substantial in 1998 to 1999. 


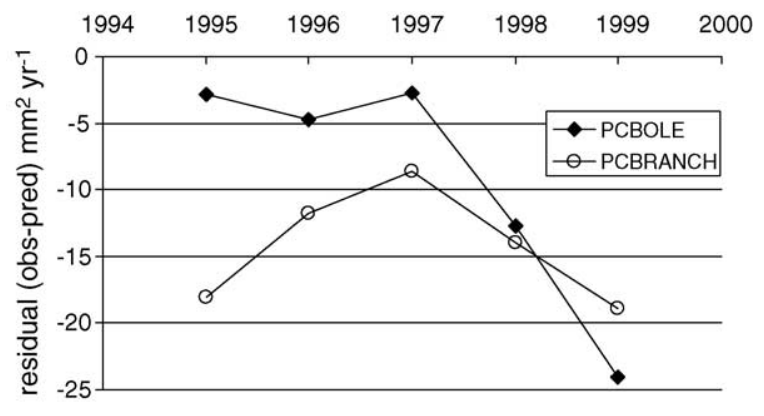

Fig. 1. Residuals of the increment sample trees (MP) by the aggregate $\mathrm{PC}$ rating and year of increment observation from a tree basal area growth model without the PC rating. Residual: observedpredicted, reference level (residual $=0$ ): trees without PC.

\subsection{Models}

The individual tree basal area increment models were the following:

Monterey pine:

$$
\begin{aligned}
\ln \left(i_{g}\right)= & \underset{(4.2468)}{8.2617}+\underset{(0.0120)}{0.1063} d-\underset{(0.00014)}{0.00071} d^{2} \\
& -\underset{(1.0973)}{1.9243} \ln (G)-\underset{(0.08261)}{0.1948 \mathrm{CIH}^{0.60}} \\
& -\underset{(0.3710)}{0.3904} \mathrm{PCBOLE} \\
& -\underset{(0.2290)}{0.3044} \mathrm{PCBRANCH} \\
& +\underset{(0.4316)}{\beta_{k}}+\underset{(0.4454)}{\varepsilon}
\end{aligned}
$$

Douglas-fir:

$$
\begin{aligned}
\ln \left(i_{g}\right)= & \underset{(2.4322)}{2.6489}+\underset{(0.0095)}{0.1332} d-\underset{(0.00009)}{0.00092} d^{2} \\
& -\underset{(0.6246)}{0.5727} \ln (G)-\underset{(0.0331)}{0.1170 \mathrm{CIH}^{0.70}} \\
& +\underset{(0.3278)}{0.4348} \mathrm{MESIC}+\underset{(0.1033)}{\beta_{k}}+\underset{(0.2487)}{\varepsilon}
\end{aligned}
$$

where $i_{g}$ is the increment of tree cross-sectional area at breast height on year $i$ of tree $j$ on plot $\mathrm{k},\left(\mathrm{cm}^{2} \mathrm{a}^{-1}\right) ; d$ is the diameter at breast height of tree $j$ on plot $\mathrm{k},(\mathrm{cm})$; $G$ is the stand basal area on plot $\mathrm{k},\left(\mathrm{m}^{2} \mathrm{ha}^{-1}\right)$; $\mathrm{CIH}$ is the competition index on year $i$ for subject tree $j$ on plot $k$, including competitors $m$ on plot $k$, of the form $\mathrm{CIH}_{j m}=\sum_{j \neq m} d_{m} / d_{j}\left(s_{j m}+1\right) ; d_{j k}$ is the diameter of subject tree $j$ on plot $k,(\mathrm{~cm}) ; d_{m k}$ is the diameter of competitor tree $m$ on plot $\mathrm{k},(\mathrm{cm}) ; s_{j m}$ is the distance from trees $j$ to $m,(\mathrm{~m})$; PCBOLE is the association of tree $j$ on plot $k$ in a $\mathrm{PC}$ rating class of $\mathrm{PC} 1-\mathrm{PC} 2$; PCBRANCH is the association of tree $j$ on plot $k$ in a PC rating class of PC3-PC5; values: $1=$ observation belongs to class, $0=$ does not belong to class; MESIC is the class variable for a mesic site $(1=$ mesic, $0=$ xeric); $\beta_{k}$ is the random plot effect; $\varepsilon_{j k}$ is the residual error.

The correlation of the Pitch canker infection assessed in 1999 with past growth (1995-1998) was treated separately from the correlation with future growth (1999) using the variables PCBOLE past $_{\text {and }}$ PCBRANCH ${ }_{\text {past }}$ in the model. However, their average effects have been added to the constant term in the final model form (3), because they have no relevance in predictions. The figures in brackets underneath each parameter value indicate its standard error.

Models for the estimation of tree height from tree diameter were constructed and used in the visual assessment of stand structure with the Stand Visualization System:

Monterey pine:

$$
\begin{aligned}
\ln (h-1.3)= & \underset{(0.6976)}{11.3873}-\underset{(0.8649)}{11.9170} d^{-0.10} \\
& -\underset{(0.1212)}{0.2427}\left(d / D_{\text {dom }}\right)+\underset{(0.0220)}{\beta_{k}}+\underset{(0.0822)}{\varepsilon_{j k}}
\end{aligned}
$$

Douglas-fir:

$$
\begin{aligned}
\ln (h-1.3)= & \underset{(0.2251)}{6.5186}-\underset{(0.3778)}{7.1664} d^{-0.20} \\
& +\underset{(0.0140)}{\beta_{k}}+\underset{(0.1037)}{\varepsilon_{j k}}
\end{aligned}
$$

where $h$ is the height of tree $j$ on plot $k,(\mathrm{~m}) ; d$ is the diameter of tree $j$ on plot $k,(\mathrm{~m}) ; D_{\mathrm{dom}(k)}$ is the dominant diameter of trees on plot $k$ (average diameter of the 100 thickest trees per hectare), $(\mathrm{cm}) ; b_{0}, \ldots b_{2}$ are fixed parameters; $\beta_{k}$ is the random plot effect and $\varepsilon_{j k}$ is the residual error.

\subsection{Tree growth}

The effects of tree diameter, species, PC infection, and stand basal area on tree diameter and basal area 


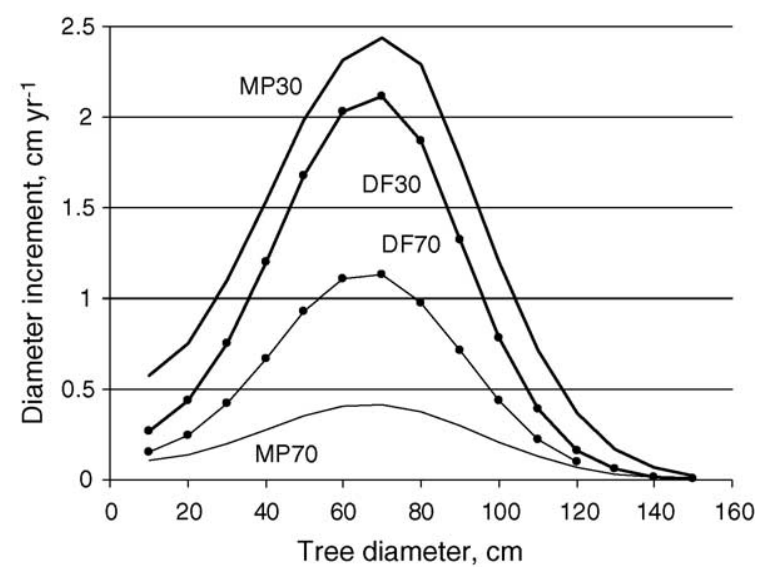

Fig. 2. Effect of tree diameter and stand basal area on the diameter increment of Monterey pine and Douglas-fir trees calculated with models 3 and 4. Stand basal area. Series labels: MP: Monterey pine, DF: Douglas-fir, number: stand basal area $\left(30\right.$ and $\left.70 \mathrm{~m}^{2} \mathrm{ha}^{-1}\right)$.

increment, calculated with the tree basal area increment models, are shown in Figs. 2 and 3. In the calculations, stand basal area was varied between approximate minimum and maximum plot values in the modeling data $\left(30-70 \mathrm{~m}^{2} \mathrm{ha}^{-1}\right)$. The competition index was scaled to represent interpolated average values for tree size and basal area in data. The results are for trees free from pitch canker or other serious disease or damage, unless otherwise indicated in specific cases.

Monterey pine trees showed a maximum diameter increment at a diameter of $70 \mathrm{~cm}$ (Fig. 2). The basal area growth culminated at about $80 \mathrm{~cm}$, respectively. Beyond that, the increment decreased rapidly, and trees with a diameter larger than $150 \mathrm{~cm}$ showed very little increment. The stand basal area had a very pronounced effect on the diameter increment. The Douglas-fir increment showed similar size dependence as Monterey pine. Its response to high or low stand density was smaller. The tolerance of Douglasfir to higher density and greater competition seemed greater than that of Monterey pine.

Trees with a pitch canker infection grew somewhat slower than those without (Fig. 3). All branch infection categories (PC3-PC5) had been aggregated to one category (PCBRANCH), and those with bole cankers or a dead top to another (PCBOLE). Variation within those categories was found to be small, and so was the difference between the two categories. The model was rather rudimentary and reflected the

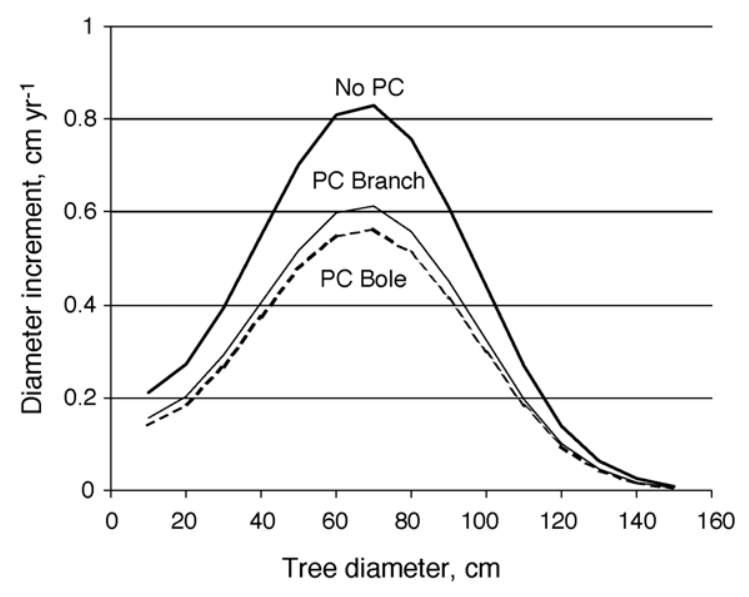

Fig. 3. Pitch Canker categories and tree diameter growth (Model 3). Stand basal area $50 \mathrm{~m}^{2} \mathrm{ha}^{-1}$. Series labels: No PC, PCBOLE: Bole canker or dead top, PCBRANCH: Few to most branches infected.

correlation between tree growth and an assessment of pitch canker in a single year (1999).

\subsection{Current stand structure}

The basal area, stand structure, and species composition varied greatly between the 17 plots within the Monterey pine aggregation (Table 2). Figs. 4a-e demonstrate the variation in stand structure, representing 9 introductory structural types that the plots were subjectively assigned according to species composition and dominance within the diameter distribution. The types were (MP - Monterey pine, DF - Douglas-fir, BL - broadleaf species); MP: MP in all size classes, with a few small BL or DF; MP + DF/BL: dominated by MP, some DF or BL among dominants; $\mathrm{MP}+\mathrm{BL}$ small: dominated by MP with a dense understory of BL; $\mathrm{DF}+\mathrm{MP} / \mathrm{BL}$ : dominated by $\mathrm{DF}$ with a major proportion of MP or BL among dominants; $\mathrm{BL}+\mathrm{MP} / \mathrm{DF}$ : Dominated by large BL, but with a major proportion of MP or DF among dominants; BL + MP/DF: dominated by $\mathrm{BL}$ with some large MP/DF; BL + MP/DF small: complete dominance by large BL with small overtopped MP or DF; MP/DF/BL sparse: a few scattered trees on the edge towards an open area.

For all species combined, most plots had inverted $J$-shaped diameter distributions resembling those typical for selection stands. The $10-30 \mathrm{~cm}$ classes generally had a high number of trees. Beyond that $(40 \mathrm{~cm}$ and over) the distributions were typically 

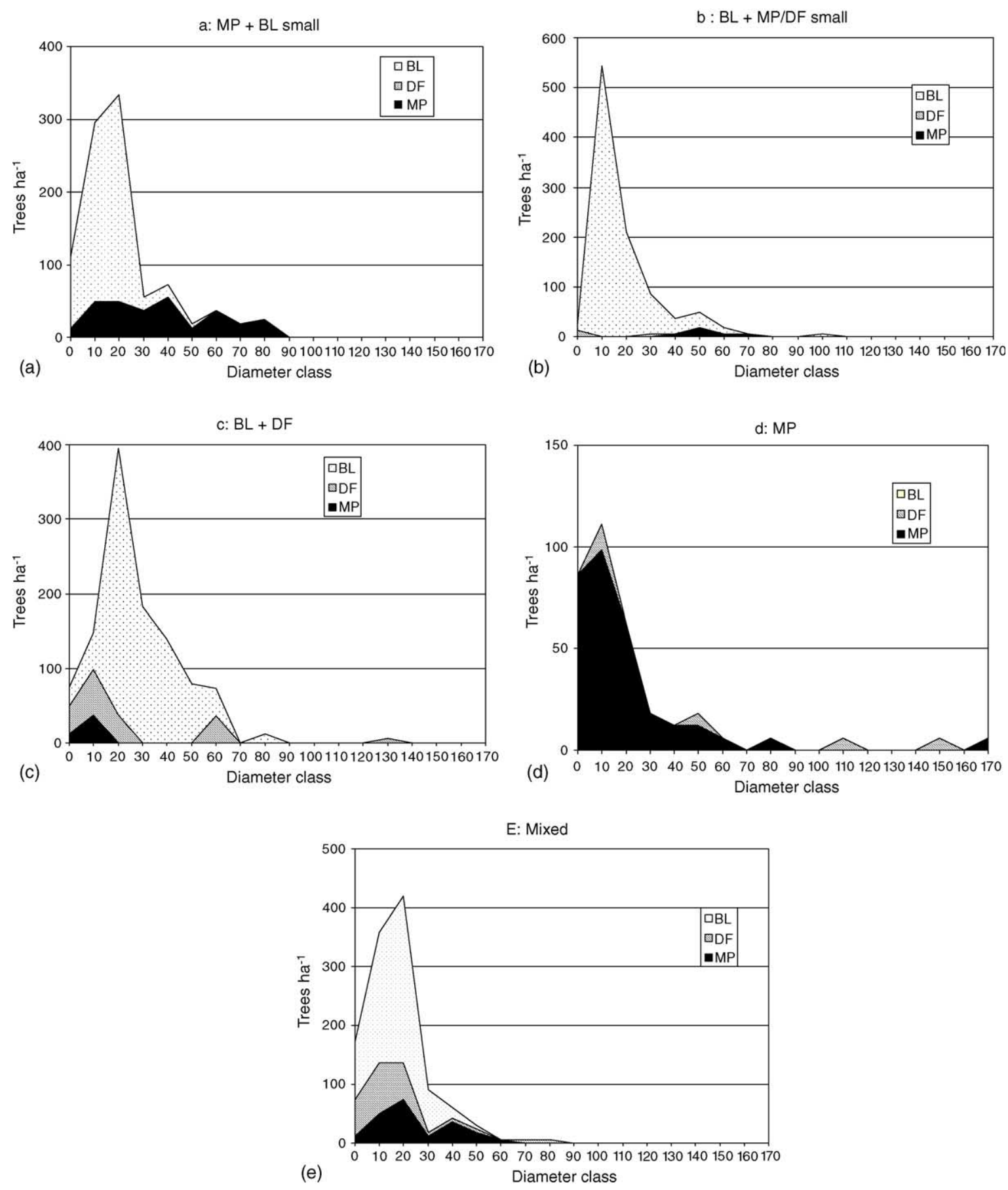

Fig. 4. Basic stand structural types on the Plots in the Monterey pine aggregation. MP: Monterey pine, DF: Douglas-fir, BL: broadleaf species. (a) MP + BLsmall = dominated by MP with a dense understory of BL (Plot 38). (b) BL + MP/DFsmall = complete dominance by large BL with small overtopped MP and DF (Plot 13). (c) BL + DF = dominated by large BL, but with a major proportion of DF among dominants (Plot 16). (d) MP: MP in all size classes, with a few small BL or DF (Plot36). (e) Mixed = MP, DF, BL almost throughout the diameter class range (Plot 45). 


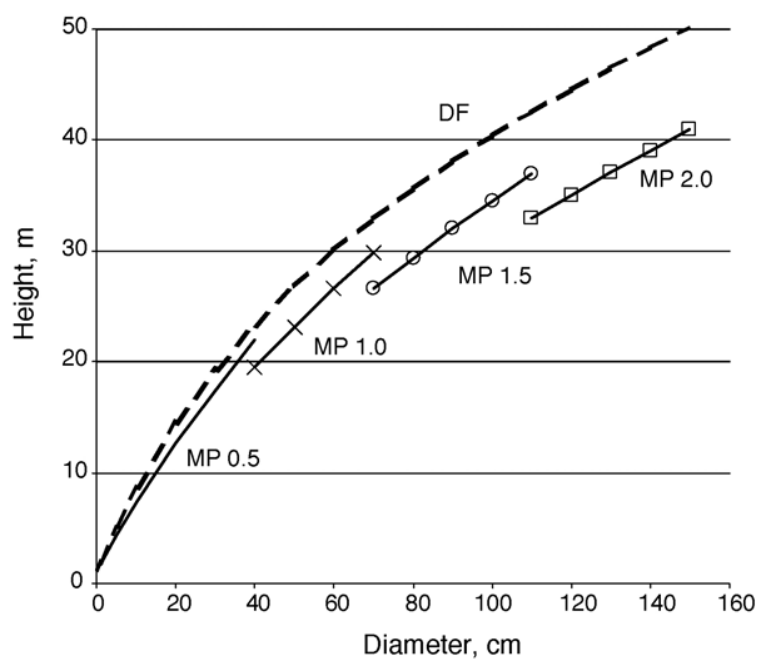

Fig. 5. Tree heights estimated with models 5 and 6 for Monterey pine (MP; $d / D_{\mathrm{dom}}=0.5,1.0,1.5$, or 2.0), and Douglas-fir (DF).

rather flat. Diameter class 20 tended to have more trees than class 10 , but not always. There were very few trees in the smallest size class $(2.54-5 \mathrm{~cm})$ on all plots, even taking the short class interval (about one quarter of the others) into account.

The results were quite different when separated by species groups. An overwhelming majority of the trees in the small diameter classes $(10-30 \mathrm{~cm})$ were broadleaves. Some plots had a considerable number of conifers in those classes. Conifers constitute a somewhat balanced selection structure alone on only $4-5$ of the plots $(9,36,37,45$; maybe 46 also). Two plots differed markedly from the general pattern. Plot 8 was a dominated by broadleafs with a very low density (basal area $5.7 \mathrm{~m}^{2} \mathrm{ha}^{-1}$ ). Plot 30 was pure extremely low density Monterey pine with a $G=0.3 \mathrm{~m}^{2} \mathrm{ha}^{-1}$.

Results calculated with the height models (5-6) suggested that large diameter Douglas-firs were somewhat taller than Monterey pines (Fig. 5). There was no height data for broadleafs, but they were generally shorter than conifers and typically belonged to the understory and, to some extent, to the intermediate canopy layers in the presence of large conifers.

\subsection{Simulated treatments}

While the initial basal area was the same in all treatments by default, its development resulted from

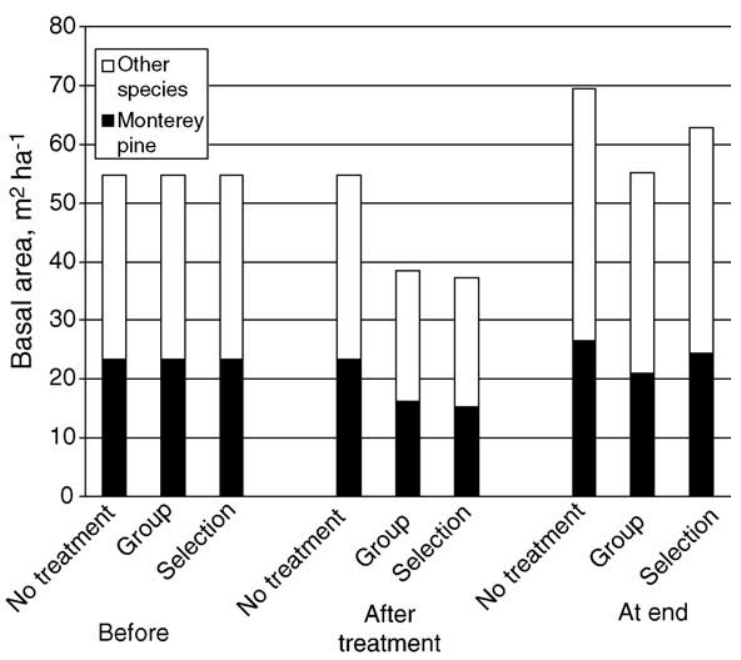

Fig. 6. Basal area before and after treatments and at the end of the 20 -year simulation period by species groups.

the combination of treatment, mortality, and increment. The highest total basal area and that of Monterey pine was retained in no treatment, and the total was reduced by about $30 \%$ and that of Monterey pine by $31-35 \%$ in the group and selection treatments (Fig. 6). The basal areas in the treatments did not regain those of the no treatment alternative during the 20-year simulation period but did make a lot of progress towards that direction, especially in the selection treatment. Compared to the initial values before the treatments, the Monterey pine basal area at the end of the 20-year simulation period was $3.14 \mathrm{~m}^{2} \mathrm{ha}^{-1}$ higher with no treatment and only $0.96 \mathrm{~m}^{2} \mathrm{ha}^{-1}$ higher in selection, but $2.36 \mathrm{~m}^{2} \mathrm{ha}^{-1}$ lower in the group treatment than the initial value. Due to the high growth rate of the other species, the proportion of Monterey pine decreased to $38.1 \%$ in no treatment, $37.9 \%$ in the group, and $38.7 \%$ in the selection treatment from the initial $42.7 \%$.

The net basal area increment after treatment of Monterey pine was highest $\left(8.94 \mathrm{~m}^{2} \mathrm{ha}^{-1}\right.$ for the 20 year-period) in the selection treatment, compared to 3.14 for no treatment and 4.67 for the group treatment. Selection also showed the greatest proportion of Monterey pine of the total net increment for all species, and the highest net increment too (Fig. 7). However, differences in the proportion of Monterey pine were small. Simulated 


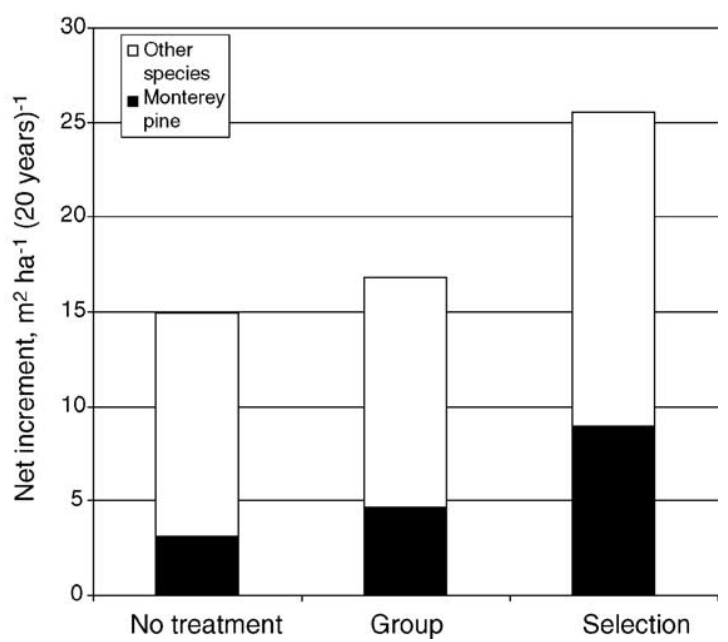

Fig. 7. Net basal area increment by treatments and species groups for the 20-year simulation period.

mortality was highest in the no treatment alternative, and lower in the group treatments. Virtually no mortality occurred in the selection treatments (Fig. 8).

The diameter increment of the small Monterey pines was greatest in the selection treatment (Fig. 9). The average increment with no treatment was only $46 \%$ of that in the selection treatment.

The growth of broadleaved trees was predicted with the Monterey pine basal area growth model in the

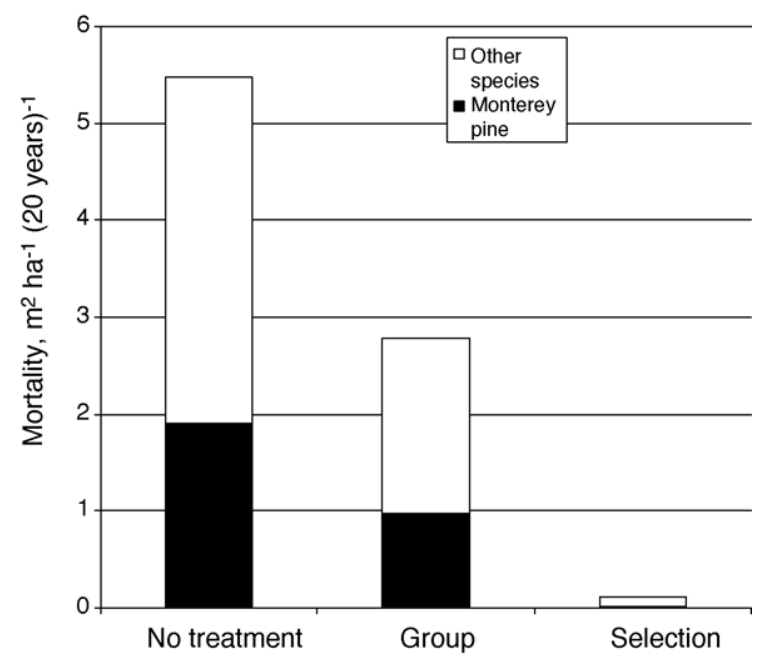

Fig. 8. Basal area mortality by treatments and species groups for the 20-year simulation period.

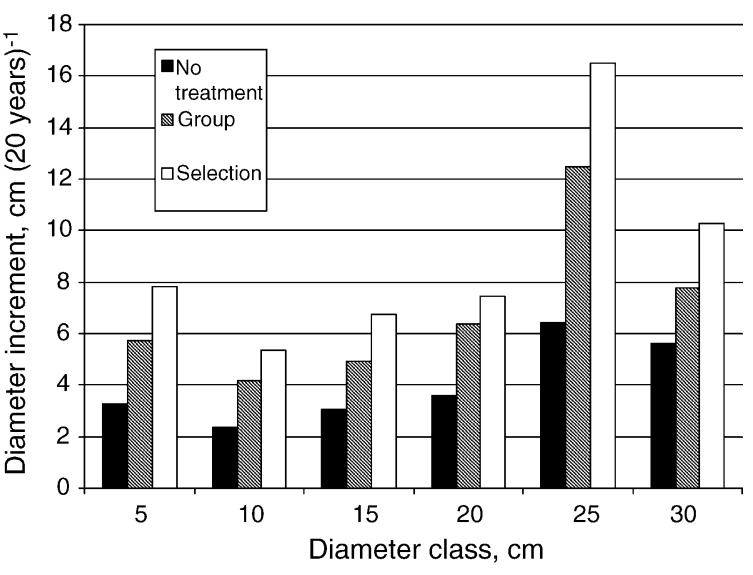

Fig. 9. Average diameter increment of small Monterey pine trees by 5 -cm diameter classes $(5-30 \mathrm{~cm})$ during the 20-year simulation period by treatments.

simulations. In order to assess the effect of potential over- or under-estimation of their growth on the results, the simulations were also performed with a $50 \%$ adjustment both downwards and upwards of the basal area increment of the broadleaved trees. If the broadleaves would in reality grow 50\% faster than Monterey pines, Monterey pine basal area net increment at the plot level in the no treatment alternative would be $61 \%$ lower than estimated, and $25 \%$ higher if broadleaf growth was $50 \%$ slower. The effect would much less pronounced in single tree ( $-3 \%$ and $+8 \%$, respectively) and group selection $(-25 \%$ and $+16 \%$, respectively) because lots of broadleaves were removed.

\subsection{Regeneration}

Of the conifer species that occurred in the survey on the Monterey pine aggregation (17 plots), only Monterey pine and Douglas-fir play a significant part in stand development. The average number of seedlings and saplings was $45 \mathrm{ha}^{-1}$ for Monterey pine and 54 for Douglas-fir. Only 23\% of the plots (or four plots) had any Monterey pine regeneration at all. Regeneration of broadleaf species was not abundant either. The average cover percentage of seedlings and saplings with $d<2.54 \mathrm{~cm}$ in the Scotts Creek stand was only 3.6, of which $44 \%$ was coast live oak/Shreve oak (Auten 2000). 


\section{Discussion}

In the face of the invasion of shade-tolerant admixture species, the absence of fire, and the pitch canker disease, effective methods and feasible guidelines for the management of native Monterey pine stands need to be initiated as soon as possible. Longterm experimentation with a representative set of treatment plots would probably yield plausible answers to management questions within 20-50 years, which was not an option in this case. The study was based on the assessment of current stand structure and species composition, tree growth, and Pitch canker infestation using data from a representative sample of intensively measured temporary plots. Modeling and simulation was applied to explore future development and the influence of treatments.

The stands currently show diameter distributions typical for selection stands only when the very numerous broadleaf (mainly Coast live oak/Shreve oak) trees in the lowest diameter classes $(10-30 \mathrm{~cm})$ are taken into account. Looking at the conifers alone, the distributions are wide but flat. Generally there are very few small conifers. Most of the stands are rather dense (basal area 40-70 $\mathrm{m}^{2} \mathrm{ha}^{-1}$ ). They are probably developing towards more closed and homogenous structures with high densities, if cuttings are not initiated. As a whole, the stands probably provide poor starting points for working towards some (yet unknown) equilibrium selection structures. There is a serious lack of regeneration and small, young, vigorous conifer trees. High densities of broadleaf trees probably block recruitment and the development and survival of seedlings. The coverage of broadleaf regeneration (seedlings and saplings) is low, and, in contrast to the larger diameter broadleaf cohorts, it does not seem to constitute a significant impediment to pine regeneration.

What the potentially sustainable equilibrium diameter distributions and stand structures might be in this particular stand or in Año Nuevo Monterey pine forests in general, remains unknown. European studies suggest that an inverted $J$-shape diameter distribution curve may not be the optimal for stand growth, and a sigmoid type distribution curve would provide an equilibrium with a higher growth level. It would involve fewer trees in the lower to middle diameters, more in the middle and higher, and less in the greatest diameter classes (Schütz, 2001). Instead of rigorous applications, the method is often utilized in improved and streamlined forms in North America (Fiedler, 1995), or replaced with more flexible approaches (see O'Hara and Valappil, 1995).

The introductory, rather subjectively applied stand structural types are just points of a continuum of stand structures resulting from the local history of stand development over time in the Monterey Pine Aggreagtion at Scotts Creek. Most structures probably evolved after recurrent fires and intensive harvesting during the first half of the 20th century (Jones and Stokes Associates, 1994; Stephens et al., 2004) that retained a varbiable but generally low number of larger, older conifers. Most of the current structures probably emerged from a gradual restocking process, creating the patch mosaic characterized by a large tree size and species composition variation. Logging interventions have been minimal in the stand during that time.

Broadleaf species, especially the overwhelmingly most abundant coast live oak/Shreve oak, are currently restricted to lower canopy layers where large conifers are present. That has resulted from the growth pattern of coast live oak/Shreve oak with rather slow height growth, and the stand history with gradual invasion of oaks from beneath. Coast live oak generally does not grow above $25 \mathrm{~m}$ and Shreve oak $17 \mathrm{~m}$ (Hickman, 1993). Since the oaks are bound to remain substantially lower than the conifers with no potential to overtop and shade them, their competition does not tend to become critical for the larger trees. Indeed, species-specific competition measures were not significant in candidate models. However, the importance of the height growth patterns and its implications to stand dynamics could not be examined because it was impossible to obtain height increment data for the oaks. It is clear, however, that broadleaf competition and shading already are extremely critical for the regeneration, survival, and growth of small conifers. Better site quality seemed to favor Douglas-fir but not Monterey pine. Because Douglas-fir grows faster and, as a long-lived tree, to greater heights than Monterey pine, tolerating higher stand densities, it seems to be gaining in dominance on the fertile sites. It may tend to become a serious competitor also to large Monterey pines in those stand areas where it is abundant. 
Results of the regeneration survey indicated that there was virtually no regeneration of Monterey pine. Sustainable uneven-aged management cannot succeed in the Año Nuevo Monterey pine complex without drastically promoting regeneration. It remains unknown whether the primary cause is low seed rain in the absence of fire, poor seedbeds, or high stand density. Even in the absence of fire, some seed rain occurs in most years with Monterey pine, and a low number of seedlings are usually present in the native stands (White, 1999).

The severity of Monterey pine pitch canker infection, assessed in 1999 with a rudimentary classification framework, influenced current and past tree growth. The infected trees had grown very slightly slower from 1995 to 1997, i.e. before and during the time when observations on pitch canker symptoms started to appear in the area, than healthy trees of similar size. The difference to healthy trees became pronounced only in 1998 to 1999 , when the major part of the infestation was observed. The infection seemed to be more abundant in the large trees with good competitive positions. That was in line with the results of Wikler et al. (2003) from Monterey peninsula, where small trees were less severely infected than large trees. Further, seedlings and saplings $(d<2.54 \mathrm{~cm})$ were less often infected $(46 \%$ infected) than large trees (90\% infected) at Scotts Creek.

Inability to predict the progress of pitch canker and its long-term effects on Monterey pine forests was a major weakness in the study as a whole and the simulation exercise in particular. Long-term trends in its progression and impacts are only now beginning to be more fully studied. Increased mortality will probably be a much more crucial issue than tree growth for the sustainability of Monterey pine in the mixed Año Nuevo stands. Consequently, long-term monitoring on the connection of pitch canker and tree mortality is in progress at Scotts Creek where 171 Monterey pine trees are annually observed for symptoms (David Yun, Cal Poly, personal communication, December 2003). A monitoring system based on annual observations on trees on sample plots has also been in place in the Monterey peninsula since 1996. The pitch canker severity rating of that system was not applied in the initial CFI measurement that provided the data for this study, because the infection was much more severe at Scotts Creek. The highest category of branch infections in that rating was $>10$ symptomatic tips, far too low to have any relevance at Scotts Creek where $70 \%$ of trees had a more severe infection. To enable future comparisons between the areas, that rating is also applied in addition to the original one in monitoring in progress at Scotts Creek. Conservative estimates on the proliferation and impact of pitch canker were applied in this study. One indication of potential validity of that approach is that the intensity of the pitch canker infection has not increased in the Scotts Creek stand since the initial assessment. According to preliminary results on annual observations on the CFI plots, symptoms on branch tips decreased between 1999 and 2001, and bole cankers and dead tops remained static. Some infected trees have died, but generally there has been no significant increase in mortality that could be unambiguously assigned to pitch canker (David Yun, Cal Poly, personal communication). Additionally, trees were harvested and assessed for pitch canker infection when the gaps for the regeneration study were established in summer and fall 2001. The sample of 577 Monterey pine trees covered much of the same area as the CFI plots, except stand edges. Only $13 \%$ of the trees had bole cankers or dead tops, compared to $35 \%$ in the sample of 1999 . Symptoms on branch tips had remained at the same level $(52 \%$ versus $54 \%$ in 1999), whereas $34 \%$ of the harvested trees had no pitch canker (10\% in 1999) (Elicia Wise, Cal Poly, personal communication).

The severest methodological limitation of the modeling and simulation approach with data from temporary sample plots was that the reliable description of the regeneration and tree mortality processes was impossible. The rather artificial maximum stand basal area limit $\left(68 \mathrm{~m}^{2} \mathrm{ha}^{-1}\right)$ that was applied to prevent excessive extrapolation in the predictions was based on the observed maximum on the plots. Basal areas of better than average stocked 50-year-old stands in Monterey averaged 48 but $100 \mathrm{~m}^{2} \mathrm{ha}^{-1}$ was observed as the maximum (see McDonald and Laacke 1990). White (1995) assessed natural changes in 19 Monterey pine stands mixed with oak between 1966 and 1994 in Monterey, discarding stands that had been modified by logging or fire from the data. The average basal area remained at a constant $58 \mathrm{~m}^{2} \mathrm{ha}^{-1}$ during the 28-29 year interval, while the number of trees decreased substantially and the average diameter 
increased. In that light, the applied limit seems not to be unrealistic, but its ultimate accuracy cannot be assessed.

However, the models should be able to give realistic average estimates for the conifer-dominated parts of the Monterey pine aggregation of the stand as a whole. Rudimentary simulations were performed to study what would happen if alternative cutting regimes were applied in the conifer-dominated parts of the stand. The treatment alternatives (none, group, and single tree selection) were considered relevant for future management decisions. In essence, the simulation results must be seen as preliminary estimates of development in Monterey pine without any treatments during the next 20 years with the current level of pitch canker influence, and how Monterey pine could benefit from group and single tree selection cuttings. The direction they point to seems clear: Monterey pine will be gradually losing growing space if cuttings are neglected. The current stand densities seem far too high for the survival and subsequent ingrowth of seedlings and saplings to the smallest diameter classes. The increasing success of coast live oak/ Shreve oak in the maturing stands seems especially harmful in the same way as in the 19 stands examined by White (1999). Cuttings to reduce stand density and the proportion of coast live oak/Shreve oak and other tolerant broadleaves seems necessary to perpetuate Monterey pine. Gaps may be more effective in promoting the regeneration, survival and growth of Monterey pine seedlings. As a seedling or sapling, it tolerates shade to some extent, but becomes less tolerant in the pole stage and is intolerant when mature (McDonald and Laacke, 1990). A field study has been launched in the Scott Creek stand that aims at examining the effect of gap of size (0.05-0.2 ha) and soil preparation on regeneration which may yield tangible results within the next 5-10 years.

\section{Conclusions}

The results indicate that the sustainability of Monterey pine is not assured with the maintenance of existing stand structures through a "no action" strategy. It might be possible to wait for the next high intensity fire to clear out these overly dense Monterey pine-broadleaf admixtures, but the results would be episodic, difficult to predict, and largely impossible to control with catastrophic effects not only on wildland values but also the intimate urban-wildland interface.

The composition and stand structure within the Scotts Creek stand and, presumably in the Año Nuevo Monterey pine stands in general, is highly variable, with the Monterey pine composition ranging from almost pure to highly mixed. Sustainability of Monterey pine is endangered in this admixture where its regeneration is lacking and the small trees are subject to very intensive shading and competition. What the potentially sustainable, target selection structures might be in this particular stand or in native Monterey pine stands in general remains unknown after this study. However, some basic features of future management seem clear.

Diameter and basal area growth of Monterey pine trees peaked in $d=70-80 \mathrm{~cm}$ trees and declined rapidly towards larger diameters. The small number of age observations and their total lack from the really large trees $(d>82 \mathrm{~cm})$ did not facilitate an examination on the relationships between tree growth and age in Monterey pine. According to McDonald and Laacke (1990), Monterey pine is short-lived and "attains full-size in 80-100 years", and "rarely lives beyond 150 years". The largest cored Monterey pines $(d=80-100 \mathrm{~cm})$ were $80-97$-years-old. Additionally, most of the very large pines have certainly reached maturity in terms of growth.

High stand density affected the growth of Monterey pine more than the growth of Douglas-firs and the shade-tolerant broadleaf species. Consequently, treatments that reduce stand density and favor mid to small diameter Monterey pines over other species and large Monterey pines seem most appropriate when aiming to promote the sustainability of Monterey pine.

In the face of the severe lack of regeneration and trees in small diameter classes, treatments that enhance regeneration and survival of small Monterey pines seem to be the key to the sustainability of the species in the study area. Gaps may be a more effective way of promoting regeneration of the intolerant Monterey pine than single tree selection. However, single tree selection cuttings would enhance the vigor and growth of Monterey pine trees across all diameter classes and advance regeneration in the stand matrix outside the gaps, especially on mesic sites that favor Douglas-fir and the broadleafs. In summary, a 
combination of gaps and single tree selection might be a good starting point for any future management regimes.

Pitch canker is affecting growth, vigor, and competitive status of Monterey pine in the stand with bole and top kill infection categories showing the most impact. The long-term prognosis of the progress of the disease and its influence on the presence and status of Monterey pine in the Scotts Creek stand and elsewhere remains unknown.

The study stand can be considered representative of the site conditions and stand structures of major parts of the Año Nuevo Monterey pine population. However, it is not safe to apply the results and models to the other populations without testing and calibration. Differences in sites, soils, stand structure and species composition, stand history, land use, and management between the mainland populations are great. The applicability of the results and conclusions of this study to any other Monterey pine stands must be carefully assessed case by case.

\section{Acknowledgements}

This study was conducted as a joint project of California Polytechnic State University, Natural Resources Management Department, and Finnish Forest Research Institute, Vantaa Research Center. It was additionally funded by a grant from the California Department of Forestry and Fire Protection and with matching funds provided through the California State University Agricultural Research Initiative. We are grateful to those institutions for resources and funding.

The Continuous Forest Inventory conducted by Steve Auten provided the basic data and some of the basic results. Walter Mark provided technical support for the fieldwork on Swanton Pacific Ranch and very valuable advice during the whole research process. David Yun, Elicia Wise, and Keven Ann Colgate conducted the additional measurements, mapping, data management, and logistical support. Peter Brown measured the tree increments at the Laboratory of Tree-Ring Research, University of Arizona, Tucson, AZ. Robert McGaughey, USDA Forest Service, Pacific Northwest Research Station, Seattle, WA, kindly introduced us to the Stand Visualization System.
Christopher Dicus, Walter Mark, Jouni Siipilehto, Richard Thompson, and Elicia Wise read the manuscript and provided valuable comments and insights. They all deserve our sincerest gratitude for making this study possible.

\section{References}

Adams, D., 1997. Monterey pine forest health. Fremontia 25, 2730.

Auten, S., 1999. Scott Creek baseline and grid system for Swanton Pacific Ranch, Natural Resources Management Department, California Polytechnic State University, San Luis Obispo, California, 9 pp., 4 appendixes.

Auten, S., 2000. Continuous Forest Inventory for Swanton Pacific Ranch-Scott's Creek Management Unit. Natural Resources Management Department, California Polytechnic State University, San Luis Obispo, California, 27 pp., 2 appendixes.

Biging, G., Dobbertin, M., 1992. A comparison of distance-dependent competition measures for height and basal area growth of individual conifer trees. Forest Sci. 38, 695-720.

Burdon, R., Bannister, M., Low, C., 1992. Genetic survey of Pinus radiata. 2. Population comparisons for growth rate, disease resistance, and morphology. New Zealand J. Forest. Sci. 22, 138-159.

California Forest Pest Council-Pine Pitch Canker Task Force, 1995. Pitch canker action plan: management, research, and educational priorities to slow the spread of pine pitch canker in California, California Department of Forestry and Fire Protection, Sacramento, California.

California Forest Practice Rules, 2003. Title 14, California Code of Regulations, Chapters 4, 4.5 and 10.

Cylinder, P., 1997. Monterey pine forest conservation strategy. Fremontia 25, 21-26.

Fiedler, C., 1995. The basal area-maximum diameter- $q$ (BDq) approach to regulating uneven-aged stands. Uneven-aged management: opportunities, constraints and methodologies. In: O'Hara, K. (Ed.), Proceedings Conference on Uneven-Aged Management: Opportunities, Constraints and Methodologies, Missoula, Montana. School of Forestry, University of Montana, pp. $94-101$.

Gordon, T., Wikler, K., Storer, A., Wood, D., 1997. Pitch canker and its potential impacts on Monterey pine forests in California. Fremontia 25, 5-9.

Hakkila, P., 1994. Pine plantations of the southern hemisphere and tropics as a source of timber. Finnish Forest Research Institute, Research Papers 532, pp. 63.

Hara, T., 1988. Dynamics of size structure in plant populations. Trends Ecol. Evol. 3, 129-133.

Hegyi, F., 1974. A simulation model for managing jack-pine stands. In: Fries, J. (Ed.), Growth Models for Tree and Stand Simulation. Royal College of Forestry, Department of Forest Yield Research, Stockholm, Sweden. Research Notes, 30, pp. 74-90.

Hickman, J. (Ed.), 1993. The Jepson Manual. Higher plants of California University of California press, Berkeley, 1400 pp. 
Huffman and Associates Inc., 1994. An evaluation of California's native Monterey pine populations and the potential for sustainability. Pebble Beach Company, Larkspur, California, 95 pp., 10 appendices.

Jones and Stokes Associates, 1994. Monterey pine ecological assessment: historical distribution, ecology, and current status of Monterey pine, California Department of Fish and Game, Natural Heritage Division, Sacramento, California, 95 pp., 10 appendices.

Lavery, P., 1990. Radiata plantation statistics NEFD and notes on Chilean, Australian and other resource descriptions. New Zealand Forest., 24-29.

Matthews, M., Nedeff, N., 1995. California's native Monterey pine forest: can it be saved? Fremontia 23 (1), 3-6.

McDonald, P., Laacke, R., 1990. Pinus radiata D. Don, Monterey pine. In: Burns, R., Honkala, P., (Eds.), Silvics of North America, Vol. 1: Conifers, Agricultural Handbook Vol. 1: Conifers. USDA Forest Service, Washington, DC, pp. 433-441.

McGaughey, R., 2001. Stand Visualization System, Version 3.30. Manual for the public domain software, Series Stand Visualization System, Version 3.30. Manual for the public domain software. USDA Forest Service, Pacific Northwest Research Station, Seattle, Washington, $141 \mathrm{pp}$.

O’Hara, K., Valappil, N., 1995. Age class division of growing space to regulate stocking in uneven-aged stands. In: O'Hara, K. (Ed.), Proceedings. Conference on Uneven-aged management: opportunitties, constraints and methodologies, Missoula, Montana. School of Forestry, University of Montana, pp. 123-143.

Owens, D., 1997. An action plan for slowing the spread of pitch canker. Fremontia 25, 31-32.
Rogers, D., 2002. In situ genetic conservation of Monterey pine (Pinus radiata D. Don): Information and recommendations. University of California, Division of Agriculture and Natural Resources, Genetic Resources Conservation Program, Davis, Reports 26, pp. 80.

Schütz, J-P., 2001.In: Der Plenterwald und Weitere Formen Strukturierter und Gemischter Wälder. Parey, Berlin, 207 pp. (in German).

Stephens, S., Piirto, D., Caramagno, D., 2004. Fire regimes and resultant forest structure in the native Año Nuevo Monterey pine (Pinus radiata) forest. California. American Midland Naturalist 152: 25-36.

Storer, A., Gordon, T., Wood, D., Dallara, P., 1995. Pitch Canker in California, California Forestry Note 110. California Department of Forestry and Fire Protection. Sacramento, California, p. 16.

Storer, A., Gordon, T., Wood, D., Bonello, P., 1997. Pitch canker disease of pines - current and future impacts. J. Forest. 95 (12), 21-26.

Storer, A., Wood, D., Gordon, T., Libby, W., 2001. Restoring native Monterey pine forests. J. Forest. 99, 14-18.

Templeton, S., Wood, D., Storer, A., Gordon, T., 1997. Economic damage of pitch canker. Fremontia 25, 10-14.

Weiner, J., 1990. Asymmetric competition in plant populations. Trends Ecol. Evol. 5, 360-364.

Weiner, J., Thomas, S., 1986. Size variability and competition in plant monocultures. Oikos 47, 211-222.

White, K., 1999. Revisiting native Pinus radiata forests after 29 years. Madrono 46, 80-87.

Wikler, K., Storer, A., Newman, W., Gordon, T., Wood, D., 2003. The dynamics of an introduced pathogen in a native Monterey pine (Pinus radiata) forest. Forest Ecol. Manage. 179, 209-221. 